\title{
Tail Risk: Part 3, The Return on Safe and Liquid Assets
}

\author{
Julian Kozlowski, Economist
}

nterest rates on government bonds fell sharply during the Financial Crisis of 2007-09. This is not particularly surprising: There are many reasons, from an increased demand for safe assets to monetary policy responses, for why risk-free rates fall during a period of financial turmoil. However, even after financial markets calmed down, this state of affairs persisted. In fact, by 2018, several years after the crisis, government bond yields showed no sign of rebounding. Figure 1 shows the change in long-term government yields for Germany, Japan, the United States, and the United Kingdom. ${ }^{1}$

Intuitively, government bonds have two key attributes: safety and liquidity. Safety refers to the observation that, different from risks for other assets in the economy, the risk of default for U.S. government bonds is almost zero, implying that at maturity the investor will almost surely receive the principal amount. Liquidity refers to the fact that government bonds are quite similar to cash, implying that if the investor needs the money before maturity, he
The liquidity of government bonds has been even more valuable since the Great Recession.

or she can easily sell the bond in the market at no discount. Both safety and liquidity naturally imply low interest rates. ${ }^{2}$ Hence, to understand the decline in real rates it is important to decompose the change in safety versus liquidity after the Great Recession.

In Parts 1 and $\underline{2}$ of this series, I argued that tail risk increased permanently after the Great Recession and showed that this increase in tail risk can help us understand the United States' slow recovery after the Great Recession. In this essay, I discuss how the increase in tail risk can also help us understand the drop in the return on safe and liquid assets.

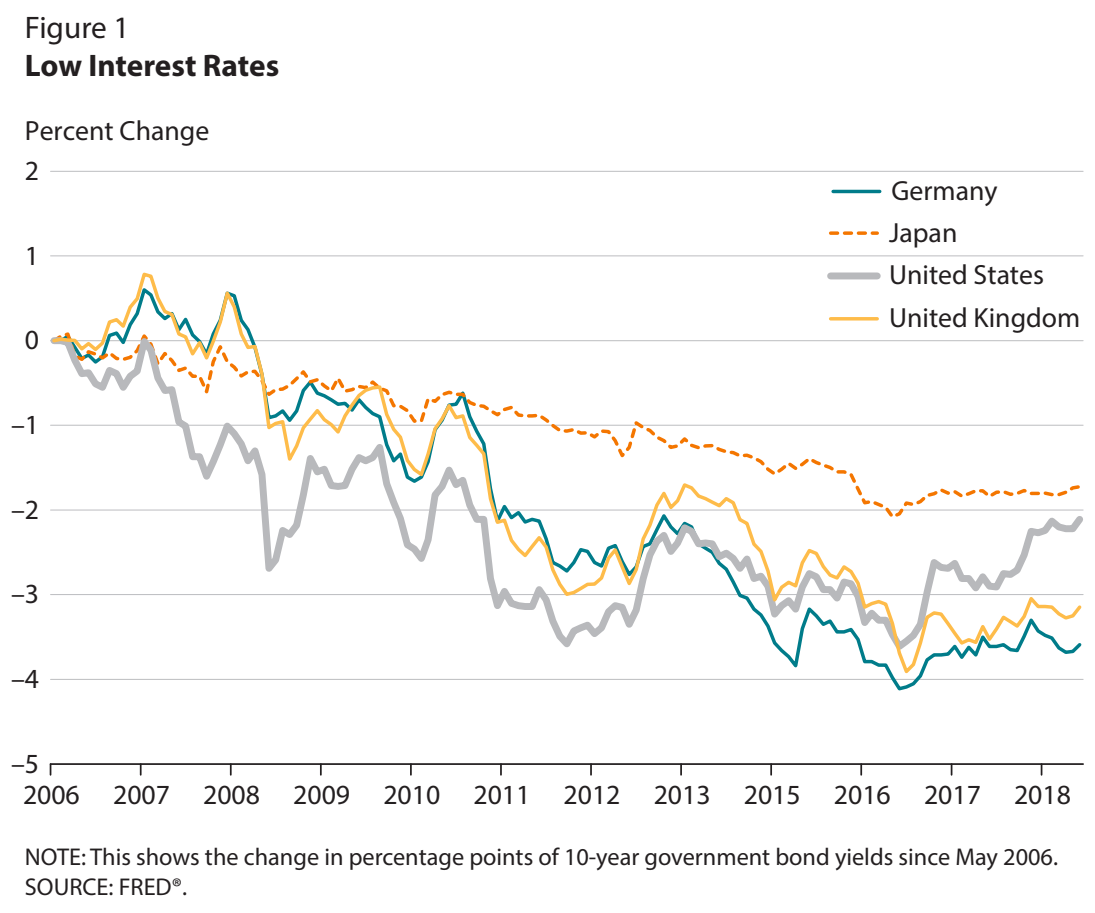


Figure 2

Risk-Free Rate

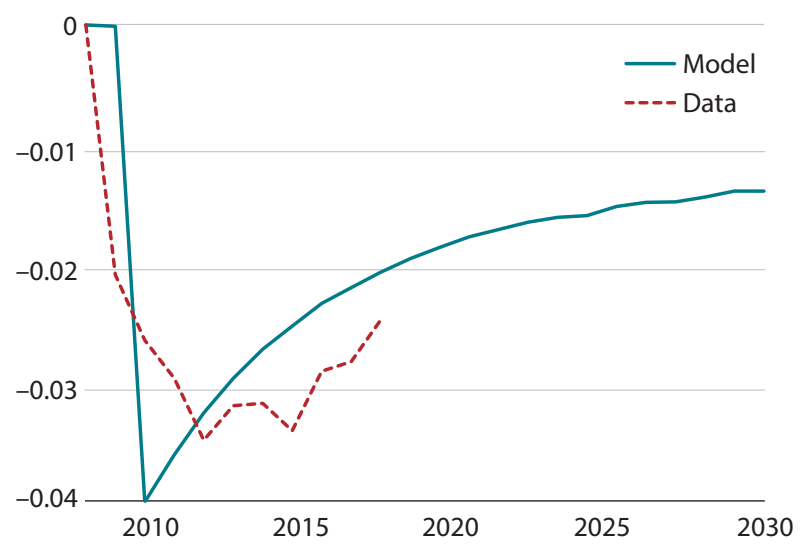

NOTE: This shows a change in the risk-free rate in the model (solid line) and U.S. data (dotted line) from the steady state (long-term average).

SOURCE: U.S. Department of the Treasury and Kozlowski, Veldkamp, and Venkateswaran, 2018.

Government bonds provide liquidity services that are particularly valuable in moments of financial distress (e.g., during the past Financial Crisis). In those periods, the liquidity available from other sources falls, so government bonds become more valuable. After the Great Recession, however, the perceived probability of a tail event (i.e., a period of financial distress) increased substantially. The increase in tail risk implies that the liquidity of government bonds is even more valuable after the Great Recession. Consequently, the increase in liquidity needs caused an increase in the price and a decrease in the return of government bonds after the Financial Crisis.

Recently, colleagues and I constructed a quantitative macroeconomic model to measure just how much the change in tail risk affected the liquidity and return on government bonds. ${ }^{3}$ Figure 2 shows the response of our model (blue line) and the data (red line) after the Great Recession. It also shows a pattern of prolonged low interest rates, where the risk-free rate never recovers from the negative shocks in 2008-09. This result is consistent with that of Del Negro et al. (2017), who also argue that the fall in risk-free rates is largely driven by the increase in the liquidity premia.
To recap, in this three-part series I explored how tail risk has affected the aggregate economy. We see that the Great Recession has reassessed the way we think about this risk. In turn, the increase in tail risk can help us understand the slow recovery after the Great Recession-the "secular stagnation"-as well as the decline in return on safe and liquid assets.

\section{Notes}

1 Looking at long-term rates allows us to abstract from transitory monetary policy and interpret the graph as evidence of a persistent decline in the level of the real rate. For additional empirical evidence, see, for example, Gomme, Ravikumar, and Rupert, 2015, and Martin, 2016.

2 If cash and bonds were perfect substitutes (i.e., perfectly indistinguishable for practical purposes), then the interest rate on bonds should be zero.

3 See Kozlowski, Veldkamp, and Venkateswaran, 2018.

\section{References}

Del Negro, Marco; Giannone, Domenico; Giannoni, Marc P. and Tambalotti, Andrea. "Safety, Liquidity, and the Natural Rate of Interest." Brookings Papers on Economic Activity, 2017, No. 1, pp. 235-316.

Gomme, Paul; Ravikumar, B. and Rupert, Peter. "Secular Stagnation and Returns on Capital." Federal Reserve Bank of St. Louis Economic Synopses, August 2015.

Kozlowski, Julian; Veldkamp, Laura and Venkateswaran, Venky. "The Tail that Keeps the Riskless Rate Low." Working Paper No. 24362, National Bureau of Economic Research, February 2018.

Kozlowski, Julian. "Tail Risk: Part 1, The Persistent Effects of the Great Recession." Federal Reserve Bank of St. Louis Economic Synopses, July 2019.

Kozlowski, Julian. "Tail Risk: Part 2, The Missing Recovery After the Great Recession." Federal Reserve Bank of St. Louis Economic Synopses, July 2019.

Martin, Fernando M. "A Perspective on Nominal Interest Rates." Federal Reserve Bank of St. Louis Economic Synopses, December 2016. 